Theatre Research in Canada

Recherches théâtrales au Canada

\title{
RICHIE WILCOX, ed. Daniel MacIvor: New Essays on Canadian Theatre, Volume 5. Toronto: Playwrights Canada Press, 2015. 257 pp.
}

T. Berto

Volume 39, Number 1, 2018

URI: https://id.erudit.org/iderudit/1055476ar

DOI: https://doi.org/10.7202/1055476ar

See table of contents

Publisher(s)

Graduate Centre for the Study of Drama, University of Toronto

ISSN

1196-1198 (print)

1913-9101 (digital)

Explore this journal

Cite this review

Berto, T. (2018). Review of [RICHIE WILCOX, ed. Daniel MacIvor: New Essays on Canadian Theatre, Volume 5. Toronto: Playwrights Canada Press, 2015. 257 pp.] Theatre Research in Canada / Recherches théâtrales au Canada, 39(1).

https://doi.org/10.7202/1055476ar

All Rights Reserved (C) Theatre Research in Canada / Recherches théâtrales au Canada, 2018
This document is protected by copyright law. Use of the services of Érudit (including reproduction) is subject to its terms and conditions, which can be viewed online.

https://apropos.erudit.org/en/users/policy-on-use/ 


\section{RICHIE WILCOX, ed.}

\section{Daniel Maclvor: New Essays on Canadian Theatre, Volume 5.}

Toronto: Playwrights Canada Press, 2015. 257 pp.

\section{T. BERTO}

This volume, edited by Richie Wilcox, offers an interesting overview of Daniel MacIvor's stage work from a variety of perspectives. While it can't possibly cover all the various explorations that MacIvor has made in three and a half decades on stage, it offers an admirable audit, illuminating not only some of the ways in which MacIvor's works have created meaning in various productions, but also examining the vast range of MacIvor's considerable theatrical skill.

The collection's expansive coverage foremost includes analyses of ideas located in particular plays or their productions (Wes Pearce on The Soldier Dreams, Jenn Stephenson on A Beautiful View, Peter Kuling on Arigato, Tokyo). While these are all interesting in their own right, this reviewer was especially interested in how Jon S. Bak brings his background on Tennessee Williams's work to ask of His Greatness, "Why Williams, why now" (206)? His investigation looks to biofiction (or biodrama in this case) ${ }^{\mathrm{I}}$ and how this genre can refute, and queer, the contextually prescribed biases inherent in more traditional, written biography. He offers that both Williams's art and the narratives associated with him-be they memoir or gossip-intertwine to make theatrical moments out of autobiographeme, all of which contain a ring of truth. ${ }^{2} \mathrm{He}$ shows then how audiences participate in the unfolding narrative of Playwright (the character) in a project of creative recovery as the tragedy of the play's story (and also Williams's biography) becomes art (219). Ultimately Bak frames the play as a work that exposes the cruelties of not only theatrical life but also homophobia, and that its construction, even if derived from gossip and ephemeral material, aptly reflects the truth of its subject.

The volume also contains comprehensive examinations which look to a number of plays, or even to a whole subgenre in MacIvor's canon (Susan Bennett, Ray Miller, Ann Wilson). Thom Bryce McQuinn's essay begins by examining the differences between the uses of the word "gay," as opposed to "queer," in I, Animal. After a quick primer on aspects of queer theory that inform that usage and its relation to heteronormativity, he finds there are "2 MacIvors" differing in how they construct his LGBTQ characters depending on the plays in which they live (I35). One MacIvor creates gay folk that verge on stereotype and "work [...] to shore up the heteronorm," while another makes queer characters that actually challenge heteronormativity (152). And while McQuinn gives context to the dramaturgical choices made, an unavoidable lesson comes through clearly: that in works of broad appeal in Canadian theatre one can still freely create homophobic expressions without fear of audience reprisal. Though MacIvor openly admits to writing in part for a "subscriber audience," McQuinn makes clear what that may entail: "revel(ling) in homophobic displays" (I53).

Other essays look more to MacIvor's plays in combination with an examination of his biography and career as a theatre maker for a more developmental analysis of the process of playmaking, or a retrospective look at his oeuvre so far (Caroline Gillis, Chris Grignard). 
Rounding out the collection, further essays include an interview by the editor with MacIvor's long-time collaborator, Daniel Brooks, and a reflective and passionate essay by MacIvor himself. In the latter, MacIvor ponders an approach to theatre as two opposing poles, the authentic versus the ego, and how it is the former that leads to communion and transformation.

Given both the diversity and size of MacIvor's catalogue, it is actually strange (as Wilcox points out) that there has not been a work like this already published. A quick search shows that the academic world has been somewhat deficient in analysing or even acknowledging MacIvor's considerable output. While this book begins to address this vacuum, there are certain areas about which this reviewer and aficionado wanted to see more-foremost is more of what McQuinn called the "2 MacIvors."

I remember how, in the late nineties at my local Little Theatre, Marion Bridge was offered to, and then flatly refused by, the board as a potential programming choice. When the person who put forth the play asked why, she was told (after some flustering) that it should be obvious that due to the play's language and subject matter, they could not program such a play. What was then immediately apparent to the play's promoter was that the board hadn't even read the play, but instead saw MacIvor's name and, aware of the Monster trilogy's recent successes, believed that his new play would be similar: that is, it would be neither the style, the content, nor the "curse-word-free" stuff they program. (As it turns out, many years later, after the huge success of Marion Bridge nationally, they belatedly put the play into their season.) They knew of one MacIvor, but not the one that had written Marion Bridge.

While McQuinn writes about MacIvor's differing representations of queerness across his body of work, what is obvious goes unsaid: that MacIvor's work changes when produced in more conservative venues (i.e. Mulgrave Road and Stratford). As Sky Gilbert notes (in Grignard's chapter), early in MacIvor's career (1988), the playwright was being torn stylistically by working at both the Tarragon, and Buddies in Bad Times - theatres with fairly different audiences, budgets, and ethos (I88). Since then MacIvor has shifted much, both in style and geography, creating work at Mulgrave Road, Stratford, and Prairie Theatre Exchange, among others. Does Mulgrave Road make for a certain kind of MacIvor? To this reviewer this seems obvious, but moreover points to how an examination of the relationship between his venues (be it their budget, rural-ness, audience age, and other parameters) and his style/subject matter aches to be brought to light.

Similarly, I would be interested in how the playwright's tenuous embrace of realism has developed over three decades. MacIvor's one-man shows also go underexplored. While the Monster Trilogy is now a half of a series of six monodramas, all developed with Brooks, there is a wealth of unexplored material there ready for analysis. Furthermore, while a number of scholars in the volume have traced how the personal aspects of MacIvor's origins in Cape Breton have strongly affected his theatre, none look to how his return there in the 2000 , his marriage and eventual divorce, and his recovery inform his work. Lastly, less of his more recent output, from the last ten years, gets acknowledged here.

These are minor quibbles, but they underscore how this volume fits into the academic coverage of such an important presence on our stages. It includes much, offering a great selection, despite the various holes in coverage. Its varying levels of investigative depth make the read at times a comfortable reflection, and at others a more rigorous academic 
pursuit. Perhaps a future volume, or volumes, might fill more holes, or dive deeper into further specific aspects of such an abundant catalogue. For now, the book serves as an excellent overview and resource.

\section{Notes}

I Bak offers that the study of biofiction is "the creative representation of a real person's life-the auto/biographical works that recount truthful stories in narrative- and dialogue-driven formats; in short, tweaking fact with fiction to make emotional sense of life" (210).

2 Bak further illuminates his terms: "Biofiction functions as a narrative historiography that reconstitutes, reorders or reconstructs [...] the biographèmes of a person's life, those individual moments or photographic impressions that represent discrete fragments of a larger truth" (2II).

\section{YVETTE NOLAN AND RIC KNOWLES, eds. Performing Indigeneity: New Essays on Canadian Theatre, Volume 6.}

Toronto: Playwrights Canada Press, 2016. 400 pp.

\section{BETHANY HUGHES}

As part of a series "on Canadian Theatre" and a "companion" to the two-volume anthology of Indigenous plays Staging Coyote's Dream, Performing Indigeneity plays its assigned roles well. It situates the specificity of First Nations theatre within a temporal and spatial setting called Canada. It also deepens engagement with the plays and playwrights found in the anthology. But it is not a study guide to Indigenous plays or an exposition on the subject of First Nations theatre. It is part of a constellation of literature that creates, sustains, and imagines a different way of working, a different way of being. Read the book to learn about Indigenous theatre in Canada, but know that in reading it you are invited to take on responsibility for its knowledge and its call for "how we should always work" (Beagan 130). The book becomes what Marrie Mumford (Métis-Chippewa Cree) exemplifies in her essay, "Kippmoojikewin": the thing(s) we carry with us.

Yvette Nolan (Algonquin/Irish) and Ric Knowles have curated a collection of essays and provided an expansive structure that results in a rich and complex invitation rather than a clearly defined answer. The essays, all written by Indigenous artists and scholars, range from short, personal pieces that trace individual histories within Canadian theatre to lengthy, scholarly analyses of performances, and quite a bit in between. Taken together they are unconcerned with creating a linear history, conveying an Indigenous stamp of approval on any specific play/playwright/theatre, or informing non-Indigenous readers about what to do as allies or advocates. Instead, these essays summon readers into what Dylan Robinson (Stó:lō) calls in the first essay of the book, the "relational operations of responsibility for knowledge" (7). Robinson supplies readers with the opportunity to rehearse and analyze their 